\title{
PALEONTOLOGICAL SOCIETY
}

\section{CANDIDATES FOR OFFICE, 1991 ANNUAL BALLOT}

At its annual meeting in Dallas, Texas, on 31 October 1990, Council of The Paleontological Society selected the following candidates for Society offices from nominees proposed by the Nominating Committee:

For:

President-Elect (1991-92): Rodney M. Feldmann, Kent, Ohio

Secretary (1991-94): Donald L. Wolberg, Socorro, New Mexico

Councilor Under 40 (1991-93): David Jablonski, Chicago, Illinois

Managing Editor, Journal of Paleontology (1991-94): Don C. Steinker, Bowling Green, Ohio

This slate will be submitted to the Membership on the Annual Ballot in August 1991. Additional nominations made in accordance with provisions of Section 3, Chapter 2 of the By-Laws will be accepted by the Secretary until 1 July 1991, and will be included as special tickets with the regular ticket announced above.

Donald L. Wolberg

Secretary

\section{ANNOUNCEMENT}

Recent applications published by the International Commission on Zoological Nomenclature in the Bulletin of Zoological Nomenclature (29 June 1990, vol. 47, pt. 2) included the following.

Case 2699. - RISSOOIDEA (or RISSOACEA) Gray, 1847 (Mollusca, Gastropoda): proposed precedence over TRUNCATELLOIDEA (or TRUNCATELLACEA) Gray, 1840.

Case 2762.-Griffithides Portlock, 1843 (Trilobita): proposed confirmation of Griffithides longiceps Portlock, 1843, as the type species, so conserving Bollandia Reed, 1943.

Recent opinions published in the same issue included the following.

Opinion 1587.-Orbitolina d'Orbigny, 1850 (Foraminiferida): Orbulites concava Lamarck, 1816, confirmed as the type species.

Opinion 1604.-ICHTHYOPHIIDAE Taylor, 1968 (Amphibia, Gymnophiona): conserved.

Comment or advice on the applications is invited for publication in the Bulletin and should be sent to the Executive Secretary, I.C.Z.N., \% The Natural History Museum, Cromwell Road, London SW7 5BD, U.K.

\section{ANNOUNCEMENT}

The following issues of Paleobiology have now sold out and are no longer available (please keep this in mind when ordering back issues):

Volume 3

Volume 4

Volume 5

Volume 6

Volume 7

Volume 8
Numbers 1, 2, and 3

Numbers 1 and 3

Number 3

Number 2

Numbers 2 and 3

Number 3 